\title{
Shirataki obsidian exploitation and circulation in prehistoric northern Japan
}

\author{
Miyuki Yakushige and Hiroyuki Sato \\ Department of Archaeology, Graduate School of Humanities and Sociology, The University of Tokyo, 7-3-1, \\ Hongo, Bunkyo-ku, Tokyo, 113-0033, Japan. \\ Email: Yakushige: nostalgiaporelpasado@yahoo.co.jp; Sato: hsato@1.u-tokyo.ac.jp
}

\begin{abstract}
:
Presently, the total number of archaeological obsidian sources in Japan is more than 80, and among them, 21 are in Hokkaido, northern part of the Japanese archipelago (Izuho and Sato 2007). Obsidian was the dominant of lithic raw material in the Upper Paleolithic Hokkaido (35-10 ka cal BP). Out of 21 archaeological obsidian sources in Hokkaido, 4 sources: Shirataki, Oketo, Tokachi, and Akaigawa are the major obsidian sources and the others are minor sources. Shirataki is one of the largest obsidian sources in Northeast Asia and it is well known that Shirataki obsidian was transported outside Hokkaido to Sakhalin and the Paleo-Honshu Island from the Late Upper Paleolithic period.

We compiled data of obsidian source analyses conducted to artefacts from Paleolithic sites in Hokkaido, and it became clear that the ratio of Shirataki obsidian in all analyzed materials is more than half (Sato and Yakushige in press).

We examined how far Shirataki obsidian was transported in each period: the Early Upper Paleolithic (35-25 ka cal BP) and the Late Upper Paleolithic (25-10 ka cal BP). The Late Upper Paleolithic is divided into three stage, the early Early Microblade Industry (Stage 1: 25-21 ka cal BP), the late Early Microblade Industry (Stage 2: 19-16 ka cal BP), and the Late Microblade Industry (Stage 3: 16-10 ka cal BP). As a result, it is revealed that the distribution areas of Shirataki obsidian did not expand gradually over time, but are different in different lithic industries. In the background of this situation lay the difference of ecological adaptation strategies adopted by the prehistoric people of the time and their movement behavioral strategies.
\end{abstract}

Keywords: Hokkaido, Sakhalin, Paleo-Honshu Island, Upper Paleolithic, obsidian, microblade industry, Lithic raw material, seafaring

\section{Introduction}

In the Japan Sea Rim Area, multiple obsidian sources have been discovered in the Russian Maritime Provinces, the middle Amur River, the border area between China and North Korea, and Hokkaido in the northern part of the Japanese archipelago (Kuzmin \& Glascock 2010). The Shirataki obsidian source is located in the eastern part of Hokkaido, and one of the largest obsidian sources in this Japan Sea Rim area. In this area, the subsistence

Published by the School of History, Classics and Archaeology, University of Edinburgh ISSN: 2055-0472. URL: http://journals.ed.ac.uk/lithicstudies/

This work is licensed under a Creative Commons Attribution 2.5 UK: Scotland License. 
strategies of modern humans displaying long distance mobility were supported by lithic technologies such as blade and microblade technology, the obsidian having been adopted as the raw material of these technologies. Therefore, obsidian source analysis data is an important clue in revealing population interaction and movement in this area.

Data from obsidian source analyses has recently been accumulated in the Japan Sea Rim area (Kuzmin \& Popov 2000; Kuzmin \& Glascock 2010), and progress has been made in the geographical/archaeological research of obsidian sources (Hall \& Kimura 2002, Izuho \& Sato 2007, Izuho et al. 2008, Izuho \& Hirose 2010, Sato 2011a, b). This has enabled us to discuss the process of human adaptation to regional environments and the circulation network of lithic raw materials by showing there was indeed utilization of each obsidian source. For example, microblade industries in Hokkaido are characterized by their use of obsidian as the main raw material and their standardization of microblade core types when compared with industries in the surrounding areas (Sato 2010). For the first step in considering the background for this difference, we compiled data from obsidian source analyses in Hokkaido and examined the quality and size of obsidian from each source, the distance between sources and sites, and the relationship between sources and industries (Sato \& Yakushige, in press). As a result, we were able to clarify that each industry in Upper Paleolithic Hokkaido had a specific tendency towards obsidian use and achieved a new understanding of the importance of the Shirataki obsidian source, that is, about half of the obsidian found in Upper Paleolithic sites in Hokkaido were from the Shirataki obsidian source. Therefore, we thought it necessary to investigate the diachronic and synchronic change of the Shirataki obsidian distribution area, and reveal how Shirataki obsidian was used in each industry and how far Shirataki obsidian was transported in prehistoric Hokkaido and surrounding areas.

\section{Geographical settings, lithic raw material resources and chronology of Upper Paleolithic Hokkaido}

\subsection{Geographical settings}

Hokkaido is located in the northern part of the Japanese archipelago. Due to a drop in sea level during the glacial period, geographical and ecological environments of the Japanese archipelago in the Upper Paleolithic were different from those of today (Figure 1). There was one large landmass named the Paleo-Honshu Island. On the contrary, the Mamiya Strait and the Soya Strait formed a land bridge, therefore Hokkaido was connected to the continent and formed the Paleo-Hokkaido Peninsula with Sakhalin and the Kuril Islands. Even more significant is that the Tsugaru Strait never had a land bridge, and Hokkaido and the PaleoHonshu Island were separated throughout the Upper Paleolithic Period.

\subsection{Lithic raw material resources}

Presently, the total number of archaeological obsidian sources in the Japanese Archipelago is more than 80, and of those, 21 are in Hokkaido (Izuho et al. 2008) (Figure 2). Within them, Shirataki, Oketo (Figure 2-a), Tokachi (Figure 2-b), and Akaigawa (Figure 2-c) are major obsidian sources. Even though siliceous shale, agate and andesite were also used, obsidian was used by far the most in Paleolithic Hokkaido. The distance between the Oketo source and the Akaigawa source is the longest, reaching about $230 \mathrm{~km}$. The Shirataki source is located on Akaishiyama Mountain in the northeastern part of Hokkaido. This source is one of the largest obsidian sources in Northeast Asia and characterized by several huge outcrops. There are many sites of various periods and industries on the fluvial terrace at the foot of the mountain, and about 100 sites around this source have been recognized so far (Naoe 2009). Since the chemical composition and characteristics of obsidian differ according to the 
outcrop, we can identify outcrops by source analysis (Wada \& Sano2011). Obsidian cobbles in various shape and size are distributed from outcrops to creeks, and the slope and river at the foot of the mountain.

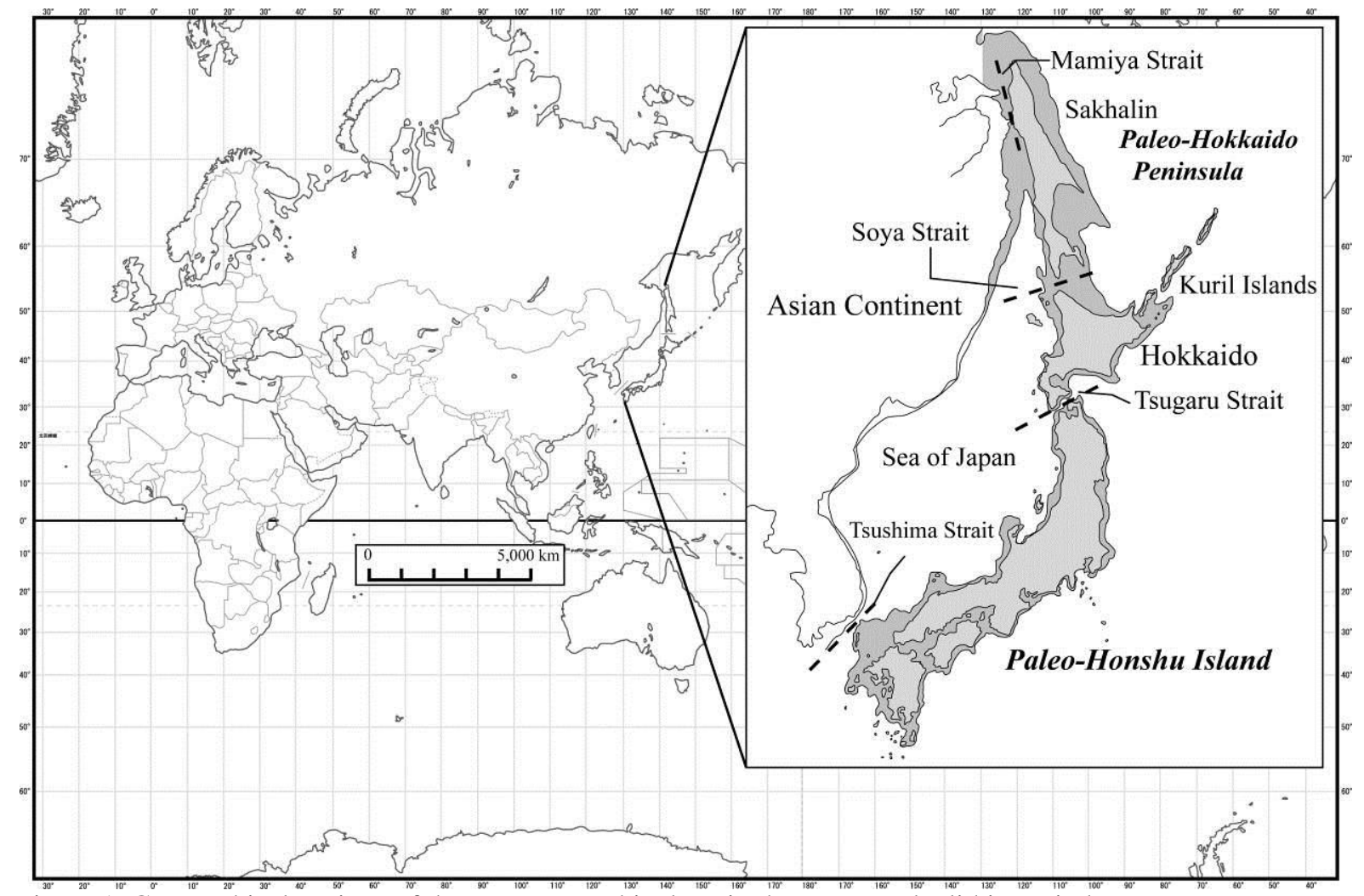

Figure 1. Geographical settings of the Japanese archipelago in the Upper Paleolithic period

\subsection{Chronology}

The chronology of Upper Paleolithic Hokkaido is largely divided into 2 periods: the Early Upper Paleolithic and the Late Upper Paleolithic (Table 1). The Late Upper Paleolithic begins with the emergence of microblade industries after $25 \mathrm{ka}$ cal BP. The Early Upper Paleolithic includes blade and trapezoid industries. The late Upper Paleolithic is divided into 3 stages (Yamada 2006) (Figure 3). Stage1 is the early Early Microblade industry, 25-21ka cal BP, Stage2 is the late Early microblade industry, 19-16ka cal BP, and Stage 3 is the Late microblade industry, 16-10ka cal BP. Stage 3 is characterized by the coexistence of various microblade industries.

Stage 1 includes the Pirika type, Tougeshita1 type and Rankoshi type microblade industries. Stage 2 includes the Sakkotsu type and Tougeshita2 type microblade industries, and stage 3 includes the Shirataki type, Oshorokko1, 2 type microblade industries, small boatshaped tool 1, 2 type industries and the point and stemmed point industries. The Sakkotsu type of Stage 2 and Shirataki type of Stage3 share the same technological feature, that being the real Yubetsu method. This method is characterized by the preparing of a biface as the blank of a microblade core and a spalling of the elongated edge for the creation of a platform. Because a cultural and social boundary was formed between the Paleo-Hokkaido Peninsula and the Paleo-Honshu Island throughout the Upper Paleolithic Period by the Tsugaru Strait, microblade industries in the Paleo-Hokkaido Peninsula and the Paleo-Honshu Island are significantly different. However, among microblade industries in Hokkaido, only the Sakkotsu type and the Shirataki type were distributed into the Paleo-Honshu Island beyond the Tsugaru Strait. Meanwhile, stemmed points appeared almost at the end of the Upper 
Paleolithic Period and are often accompanied with microblade industries. They were not accompanied by pottery in Hokkaido, but at the same time in Paleo Honshu Island, they were accompanied by the earliest pottery and belong to the Initial Jomon period.

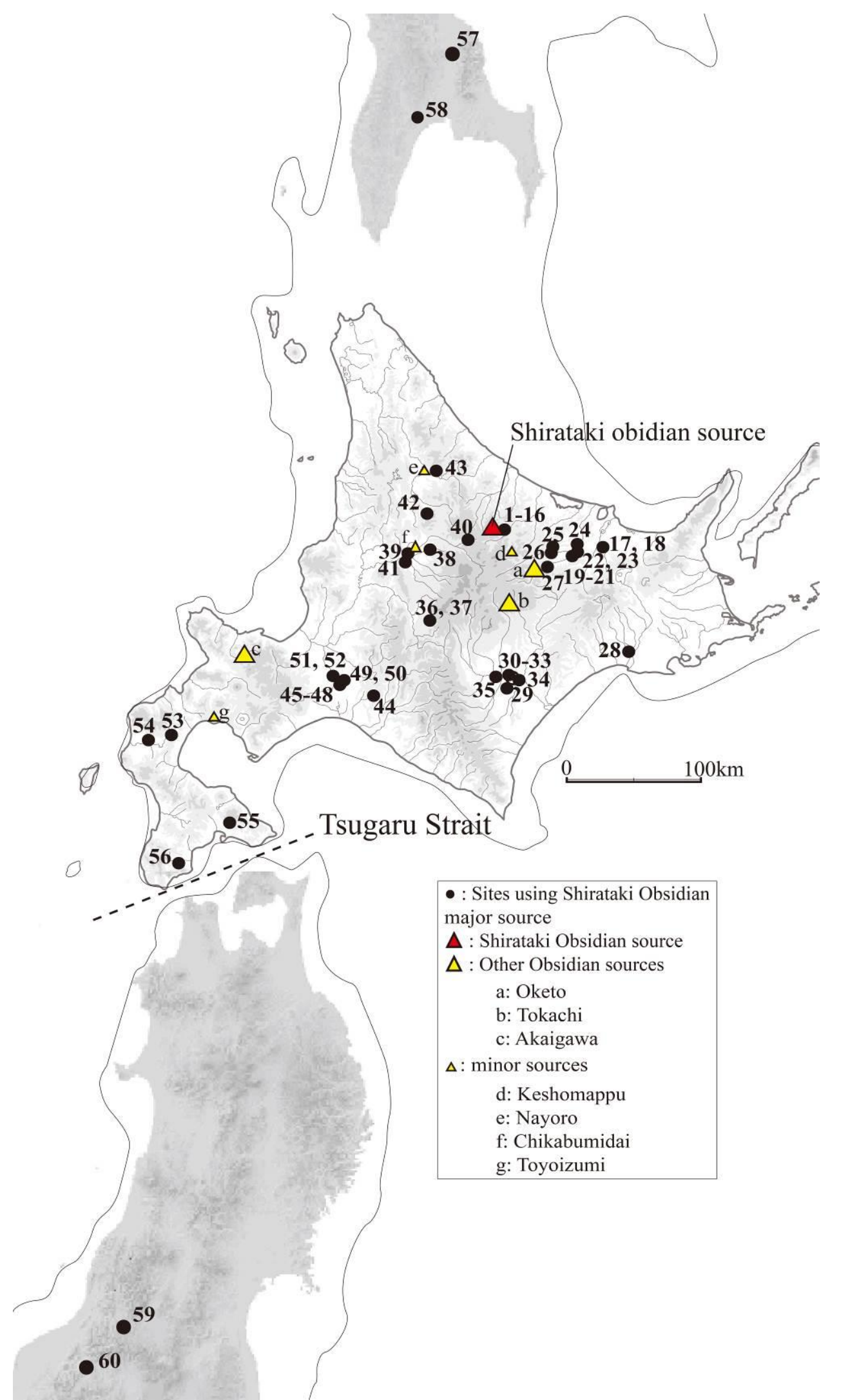

Figure 2. Obsidian sources in Hokkaido and Upper Paleolithic sites in which Shirataki obsidian was found 
Table 1. Chronology of Upper Paleolithic Hokkaido.

\begin{tabular}{lll}
\hline \multicolumn{1}{c}{ period } & \multicolumn{1}{c}{ stage } & \multicolumn{1}{c}{ industry } \\
\hline $\begin{array}{l}\text { Early Upper } \\
\text { Paleolithic } \\
(35-25 \mathrm{ka} \mathrm{cal} \mathrm{BP})\end{array}$ & & Trapezoid and blade \\
\hline & $\begin{array}{l}\text { 1. early Early Microblade } \\
\text { Industry }(25-21 \mathrm{ka} \mathrm{cal} \mathrm{BP})\end{array}$ & $\begin{array}{l}\text { Rankoshi type Microblade } \\
\text { Tougeshita 1 type Microblade } \\
\text { Pirika type Microblade }\end{array}$ \\
\cline { 2 - 3 } & 2. late Early Microblade Industry & $\begin{array}{l}\text { Sakkotsu type Microblade } \\
\text { Tougeshita 2 type Microblade }\end{array}$ \\
\cline { 2 - 3 } $\begin{array}{l}\text { Late Upper Paleolithic } 16 \mathrm{ka} \mathrm{cal} \mathrm{BP}) \\
(25-10 \mathrm{ka} \text { cal BP })\end{array}$ & & $\begin{array}{l}\text { Shirataki type Microblade } \\
\text { Oshorokko 1 type Microblade }\end{array}$ \\
& & $\begin{array}{l}\text { Oshorokko 2 type Microblade } \\
\text { Small boat-shaped tool 1 type }\end{array}$ \\
& 3. Late Microblade Industry & Small boat-shaped tool 2 type \\
& & Point and stemmed point \\
\hline
\end{tabular}

\section{Materials and methods}

The number of Upper Paleolithic sites in Hokkaido is 861 as of 2010 (Japanese Paleolithic Research Association 2010). We compiled the obsidian source analysis data of the Upper Paleolithic in and around Hokkaido reported thus far, including data from several laboratory analysis methods such as XRF and INAA. As a result, the number of sites where obsidian source analysis was done is 84 , yielding 5,461 artifacts. This means only $9.8 \%$ of all Upper Paleolithic sites in Hokkaido have been analyzed. From this data, we extracted sites in which Shirataki obsidian was found in each period and industry ${ }^{1}$ (Table 2). Out of 5,461 artifacts from 84 sites, 2,720 artifacts $(49.8 \%)$ from 56 sites are made from Shirataki obsidian. Then, we examined the change of Shirataki obsidian distribution areas in each industry. Paying careful attention to detail was important in analyzing this data. Because a few samples for analysis were chosen from thousands of artifacts in a random manner in some analyses, the results of these analyses do not necessarily show complete or actual tendency of obsidian use. However, we think we can at least recognize the tendency in transportation of Shirataki obsidian from these data. 


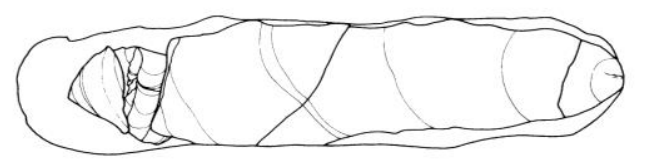

Pirika type
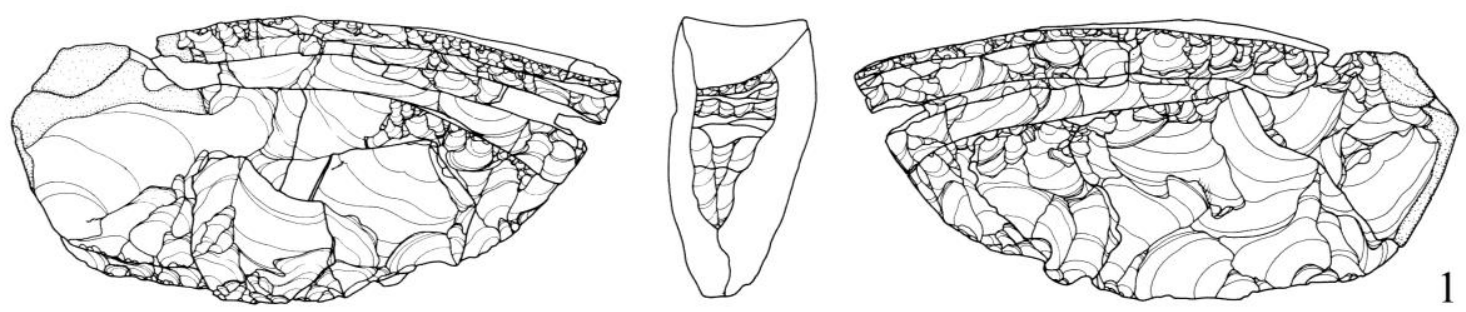
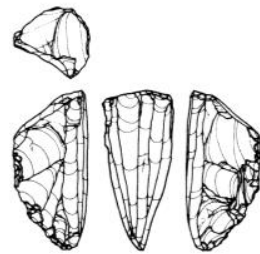

Rankoshi type
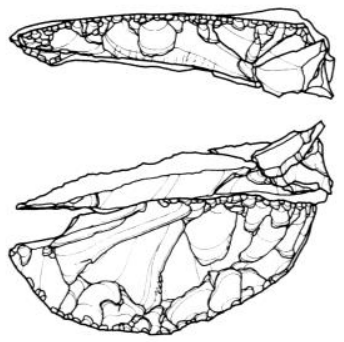

2

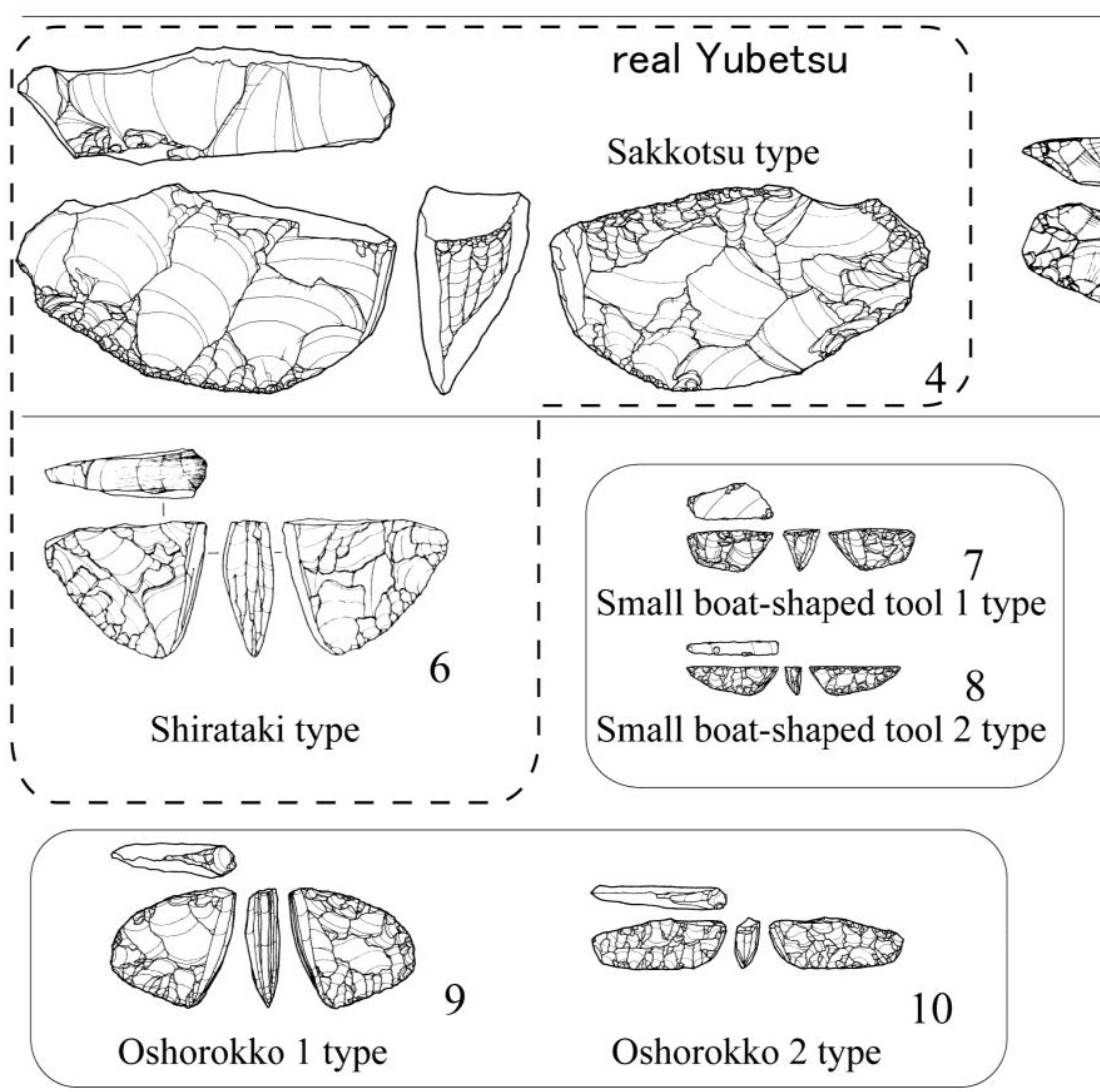

Tougeshita 2 type
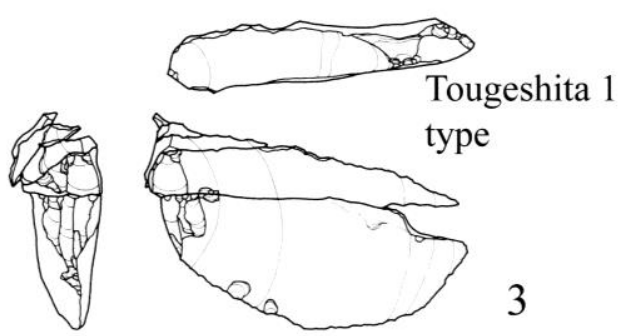

3

Figure 3. Microblade industries in the Upper Paleolithic Hokkaido 
Table 2. Compiled data of sites in which Shirataki obsidian was found in Hokkaido and surrounding areas.

\begin{tabular}{|c|c|c|c|c|c|c|c|}
\hline Area & No. & Site & Industry & $\begin{array}{l}\text { Number of } \\
\text { analyzed } \\
\text { material }\end{array}$ & $\begin{array}{l}\text { Number of } \\
\text { excavated } \\
\text { materials }\end{array}$ & $\begin{array}{l}\text { Number of artifacts made } \\
\text { by S hirataki obsidian }\end{array}$ & Refference \\
\hline \multirow{62}{*}{ 苞 } & \multirow{7}{*}{1} & \multirow{7}{*}{ Hattoridai2 } & 1 & 3 & 7 & 2 & \multirow{7}{*}{ Warashina2007 } \\
\hline & & & 2-B-2 & 3 & Unknown & 2 & \\
\hline & & & 2-C-1 & 3 & Unknown & 3 & \\
\hline & & & $2-C-3$ & 7 & $>10173$ & 7 & \\
\hline & & & $2-\mathrm{C}-5$ & 23 & 30959 & 14 & \\
\hline & & & \begin{tabular}{|l|}
2 \\
\end{tabular} & 27 & \multirow{2}{*}{67747} & 20 & \\
\hline & & & $1 \cdot 2$ & 7 & & 3 & \\
\hline & \multirow{6}{*}{2} & \multirow{6}{*}{ Shiratakihattoridai } & 2-B-2 & 8 & \multirow{6}{*}{31693} & 7 & \multirow{6}{*}{$\begin{array}{l}\text { Meiji Univ. Cultural Propertics } \\
\text { Lab. } 2011 \\
\end{array}$} \\
\hline & & & \begin{tabular}{|l|}
$2-\mathrm{C}-1$ \\
\end{tabular} & 67 & & 61 & \\
\hline & & & $2-\mathrm{C}-3$ & 9 & & 9 & \\
\hline & & & \begin{tabular}{|l|}
$2-\mathrm{C}-5$ \\
\end{tabular} & 2 & & 1 & \\
\hline & & & 2 & 78 & & 73 & \\
\hline & & & $1 \cdot 2$ & 1905 & & 1509 & \\
\hline & \multirow{3}{*}{3} & \multirow{3}{*}{ Okushirataki1 } & 1 & 9 & 1289 & 8 & Warashina2002a \\
\hline & & & 2-C-5 & 28 & 58020 & 19 & \multirow{2}{*}{ Warashina2002a, 2007} \\
\hline & & & $1 \cdot 2$ & 8 & 29939 & 4 & \\
\hline & & & 2-B-1 & 5 & 5888 & 5 & \\
\hline & & & 2-C-2 & 3 & 1799 & 2 & \\
\hline & 4 & Kamishirataki2 & $2-\mathrm{C}-3$ & 2 & 5766 & 2 & Warashina2001 \\
\hline & & & $2-\mathrm{C}-5$ & 5 & 35538 & 5 & \\
\hline & & & 2-B-1 & 3 & 94 & 3 & \\
\hline & 5 & Kamis hirataki5 & 2-C-3 & 27 & 9758 & 21 & Warashina2002a \\
\hline & & & 2-C-5 & 14 & 11315 & 14 & \\
\hline & 6 & Kamishirataki6 & 2-C-5 & 6 & 1343 & 6 & Warashina2001 \\
\hline & 7 & Kamishirataki7 & 1 & 54 & 2339 & 54 & Warashing $2000_{a}$ \\
\hline & 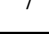 & Ramisminatak1/ & $2-\mathrm{C}-5$ & 11 & 1987 & 11 & warasinilazuva \\
\hline & & & 1 & 41 & 60818 & 41 & Warashina2004, 2006 \\
\hline & & & 2-A-1 & 1 & Unknown & 1 & \\
\hline & & & 2-A-2 & 10 & 26522 & 9 & \\
\hline & 8 & Kamishirataki8 & $2-\mathrm{A}-3$ & 1 & Unknown & 1 & Warashina2004 \\
\hline & & & 2-C-3 & 9 & 31571 & 6 & \\
\hline & & & 2-C-5 & 15 & 65023 & 8 & \\
\hline & & & 2 & 17 & 206818 & 17 & Warashina2004 2006 \\
\hline & & & $1 \cdot 2$ & 12 & 215783 & 4 & warasninaz004, 2006 \\
\hline & & & 2-C-3 & 33 & 1009 & 32 & \\
\hline & 0 & Shirataki3 & $2-\mathrm{C}-5$ & 4 & & 4 & \\
\hline & 9 & snıratakıs & 2 & 5 & 41271 & 3 & \\
\hline & & & $1 \cdot 2$ & 16 & & 11 & Jhutsuzairyokenkyuio2007 \\
\hline & & & 2-B-2 & 5 & 138 & 5 & IDutsuzarry okenky ujozo0/ \\
\hline & 10 & Shirataki8 & 2 & 4 & 4030 & 4 & \\
\hline & 11 & Shirataki18 & 2-C-5 & 41 & 23331 & 40 & \\
\hline & & & 2-B-2 & 2 & 6085 & 2 & \\
\hline & & & $2-\mathrm{C}-3$ & 4 & 4835 & 4 & \\
\hline & 12 & Shirataki Loc. 30 & $2-\mathrm{C}-5$ & 3 & 8954 & 2 & Inoue 2003 \\
\hline & & & \begin{tabular}{|l|}
2 \\
\end{tabular} & 11 & 71240 & 5 & \\
\hline & & & $1 \cdot 2$ & 8 & 11249 & 3 & \\
\hline & & & $2-\mathrm{C}-3$ & 3 & 2185 & 3 & \\
\hline & 13 & HorokazawaI & $2-\mathrm{C}-5$ & 2 & 10237 & 1 & Jhutcurairugkenkwio 011 . \\
\hline & 13 & Horokazawal & 2 & 20 & 115574 & 19 & Ibutsuzarry okenky ujo2011b \\
\hline & & & $1 \cdot 2$ & 7 & $1133 / 4$ & 7 & \\
\hline & & & 1 & 4 & & 4 & \\
\hline & & & $2-\mathrm{A}-2$ & 15 & 32731 & 14 & \\
\hline & 14 & Kyushirataki5 & 2-C-2 & 1 & & 1 & Ibutsuzairy okenky ujo2008 \\
\hline & & & 2 & 44 & 261571 & 41 & \\
\hline & & & $1 \cdot 2$ & 7 & & 7 & \\
\hline & & & 2-A-1 & 7 & 12961 & 3 & \\
\hline & & & \begin{tabular}{|l|}
$2-B-2$ \\
\end{tabular} & 5 & 10079 & 5 & \\
\hline & 15 & Kуushirataki15 & $2-\mathrm{C}-3$ & 13 & $100 / 9$ & 11 & Jhutcuzairykenkuiposo \\
\hline & 15 & | Куusnirataki1s & 2-C-5 & 3 & 12318 & 2 & IDutsuzanry okenky ujozoiz \\
\hline & & & 2 & 5 & 25541 & 5 & \\
\hline & & & $1 \cdot 2$ & 13 & 35541 & 1 & \\
\hline & 16 & Kyushirataki16 & 1 & 7 & 1807 & 2 & Ibutsuzairy okenky ujo2009 \\
\hline$\exists$ & 17 & Motomachi2 & 2 & 140 & 148 & 45 & Kannari·Sugihara2006 \\
\hline : & 18 & Midoril & 2 & 119 & 653 & 58 & Kannari·sugharazovo \\
\hline 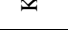 & 19 & Hirosato8 & 1 & 9 & 14218 & 1 & Warashina Higashimura1985c \\
\hline
\end{tabular}




\begin{tabular}{|c|c|c|c|c|c|c|c|}
\hline Area & No. & Site & Industry & \begin{tabular}{|l|}
$\begin{array}{l}\text { Number of } \\
\text { analyzed } \\
\text { material }\end{array}$ \\
\end{tabular} & \begin{tabular}{|l}
$\begin{array}{l}\text { Number of } \\
\text { excavated } \\
\text { materials }\end{array}$ \\
\end{tabular} & \begin{tabular}{|l}
$\begin{array}{l}\text { Number of artifacts } \\
\text { made by Shirataki } \\
\text { obsidian }\end{array}$ \\
\end{tabular} & Refference \\
\hline \multirow{14}{*}{ 咅 } & 20 & Kitakamidaichi & 2-C-4 & $\begin{array}{r}40 \\
\end{array}$ & 40 & 1 & Warashina $\cdot$ Higashimura1984 \\
\hline & 21 & Kitakami4 & 2 & 20 & 1095 & 1 & Ibutsuzairy okenky ujo2011a \\
\hline & 22 & Kawahigashi16 & 2 & 75 & 32889 & 4 & Ibutsuzairy okenky ujo2010 \\
\hline & \multirow[b]{2}{*}{23} & \multirow{2}{*}{ Kawahigashi3 } & $2-\mathrm{C}-3$ & 13 & \multirow{2}{*}{26639} & 3 & \multirow{2}{*}{ Ibutsuzairy okenky ujo2011c } \\
\hline & & & 2 & 43 & & 12 & \\
\hline & 24 & Hokushin & $2-\mathrm{A}-2$ & 120 & 2126 & 10 & Warashina1998 \\
\hline & \multirow{2}{*}{25} & \multirow{2}{*}{ Momijiyama } & $2-\mathrm{C}-3$ & 6 & 2185 & 6 & \multirow{3}{*}{ This study } \\
\hline & & & 2 & 13 & 2185 & 2 & \\
\hline & 26 & Yoshiizawa Loc.UT & $2-\mathrm{C}-4$ & 22 & 13694 & 3 & \\
\hline & \multirow{5}{*}{27} & \multirow{5}{*}{ Oketoazumi } & 2-B-1 & 18 & \multirow{5}{*}{$>40,000$} & 2 & \multirow{5}{*}{$\begin{array}{l}\text { Sugihara et al.2009, } \\
\text { Toy ohara·Sakai2011 }\end{array}$} \\
\hline & & & $2-\mathrm{C}-1$ & 17 & & 1 & \\
\hline & & & $2-\mathrm{C}-3$ & 3 & & 1 & \\
\hline & & & 2 & 23 & & 3 & \\
\hline & & & $1 \cdot 2$ & 377 & & 5 & \\
\hline \multirow{8}{*}{$\begin{array}{l}\text { 节 } \\
\text { 音 } \\
\text { r }\end{array}$} & 28 & Hokuto & 2-C-5 & 1 & 1484 & 1 & Koshimizu1994 \\
\hline & 29 & KukominamiA & 1 & 2 & 30 & 1 & Warashina1993 \\
\hline & 30 & Ozora & 2-C-4 & 5 & 3997 & 1 & Higashimura $\cdot$ Warashina1995 \\
\hline & 31 & Minamimachi2 & 2-B-1 & 4 & 574 & 4 & Warashina1997a \\
\hline & 32 & Akatsuki & 2-B-1, 2 & 70 & $>14186$ & 30 & \begin{tabular}{|l|} 
Warashina1993, \\
Higashimura•Warashina1995
\end{tabular} \\
\hline & 33 & Ochiai & $2-\mathrm{C}-3$ & 22 & 7069 & 6 & $\begin{array}{l}\text { Warashina1993, 1999a, 2002c, } \\
\text { Higashimura·Warashina1995 }\end{array}$ \\
\hline & 34 & Kamiitaira & 2-B-1 & 30 & 488 & 16 & Warashina2002b \\
\hline & 35 & Kitafushiko2 & 2 & 8 & 974 & 6 & Warashina2000b \\
\hline \multirow{10}{*}{ 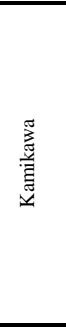 } & 36 & Higashirokugo 1 & $2-\mathrm{C}-5$ & 79 & 2744 & 3 & \multirow{2}{*}{ Warashina·Higashimura1987b } \\
\hline & 37 & Higashirokugo 2 & 2-C-4 & 123 & 4603 & 101 & \\
\hline & 38 & Sakuraoka5 & 2 & 5 & 468 & 5 & Yoshitani2001 \\
\hline & 39 & Arashiyama2 & 2-C-4 & 32 & 1750 & 25 & Warashina $\cdot$ Higashimura1987a \\
\hline & 40 & Nitto & $2-\mathrm{C}-2$ & 20 & 2708 & 1 & $\begin{array}{l}\text { Meiji Univ. Cultural Propertics } \\
\text { Lab. } 2009\end{array}$ \\
\hline & 41 & Kyoei7 & $1 \cdot 2$ & 24 & ca. 10 & 22 & Nakatani $\cdot$ Wada2010 \\
\hline & 42 & Higashimachi & 2-B-2 & 1 & 2 & 1 & Warashina2000c \\
\hline & \multirow{3}{*}{43} & \multirow{3}{*}{ Nis $\operatorname{shin} 2$} & 1 & 13 & 23 & 2 & \multirow{3}{*}{$\begin{array}{l}\text { Koshimizu1988a, } \\
\text { Warashina·Higashimura1988 }\end{array}$} \\
\hline & & & $2-\mathrm{B}-2$ & 12 & \multirow{2}{*}{1324} & 10 & \\
\hline & & & $1 \cdot 2$ & 62 & & 36 & \\
\hline \multirow{9}{*}{ 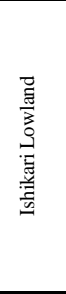 } & 44 & Kamihoronaimoi & 2-B-1 & 134 & 1412 & 8 & This study \\
\hline & 45 & Shukubaisankakuyama & 1 & 12 & 211 & 2 & Koshimizu1981 \\
\hline & 46 & Shukubaigawaueda & 2-B-1 & 20 & 6420 & 20 & Takehara2013 \\
\hline & 47 & Kashiwadail & 1 & 13 & 29213 & 4 & Warashina1999b \\
\hline & 48 & Ankarito7 & 2-B-2 & 3 & 23 & 3 & Takehara2010 \\
\hline & 49 & Oruika2 & 2-B-1 & 5 & 2671 & 2 & Warashina2003 \\
\hline & 50 & Kiusu9 & 2 & 3 & 9 & 1 & Takehara2008 \\
\hline & 51 & Osatsu 16 & 2-B-2 & 12 & 2260 & 5 & $\begin{array}{l}\text { Kondo } \cdot \text { Warashina1998b, } \\
\text { Warashina1997b }\end{array}$ \\
\hline & 52 & YukanboshiC15 & 1 & 3 & 3 & 2 & Warashina1999c \\
\hline \multirow{6}{*}{ 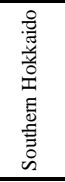 } & & & $2-\mathrm{C}-3$ & 8 & 4832 & 1 & \\
\hline & 53 & Pirika1 & 2 & 107 & 110316 & 8 & Warashina $\cdot$ Higashimural985b \\
\hline & 54 & Kamioka2 & $2-\mathrm{C}-3$ & 4 & 6229 & 1 & Koshimizu1990 \\
\hline & 55 & Ishikawa1 & 2-C-1 & 6 & 8781 & 6 & Koshimizu1988b \\
\hline & & & 2-B-2 & 105 & & 12 & \\
\hline & 56 & Yunosato4 & $2-\mathrm{C}-5$ & 1 & ca. 20,000 & 1 & Warashina $\cdot$ Higashimura1985a \\
\hline Total & & & & 4722 & $>1,852,227$ & 2698 & \\
\hline
\end{tabular}

\begin{tabular}{|c|c|c|c|c|c|c|c|}
\hline \multirow{2}{*}{ Sakhalin } & 57 & Sokol & 2-B-1 & \multirow{2}{*}{ Unknown } & \multirow{2}{*}{ Unknown } & \multirow{2}{*}{\multicolumn{2}{|c|}{ Kuzmin et al.2002 }} \\
\hline & 58 & Ogonki5 (Layer2b) & $2-\mathrm{C}-3$ & & & & \\
\hline \multirow{2}{*}{ Honshu } & 59 & Yunohana & $2-\mathrm{C}-1$ & 6 & Unknown & 3 & Tateishi et al.2012 \\
\hline & 60 & Kosegasawa & $2-\mathrm{C}-5$ & 11 & Unknown & 2 & Warashina and Oguma2003 \\
\hline
\end{tabular}

\footnotetext{
Legend

1 Early Upper Paleolithic

2 Late Upper Paleolithic

2-A early Early Microblade Industry

2-A-1 Rankoshi type microblade industry

2-A-2 Tougeshita 1 type microblade industry

2-A-3 Pirika type microblade industry

2-B late Early Microblade Industry

2-B-1 Sakkotsu type microblade industry
}

$\begin{array}{ll}\text { 2-B-2 } & \text { Tougeshita } 2 \text { type microblade industry } \\ \text { 2-C } & \text { Late Microblade Industry } \\ \text { 2-C-1 } & \text { Shirataki type microblade industry } \\ \text { 2-C-2 } & \text { Hirosato type microblade industry } \\ \text { 2-C-3 } & \text { Small boat-shaped tool type industry } \\ \text { 2-C-4 } & \text { Oshorokko type microblade industry } \\ \text { 2-C-5 } & \text { bifacial point or stemmed point industry }\end{array}$ 


\section{Results}

\subsection{The Early Upper Paleolithic (35-25 ka cal BP)}

We focus first on sites of the Early Upper Paleolithic, 35-25 ka cal BP (Figure 4). This stage includes trapezoid industry and blade tool industry. Figure 5 shows sites using Shirataki obsidian in the Early Upper Paleolithic. In this period, Shirataki obsidian was not transported outside of Hokkaido, but transported over a relatively wide area. The longest distance of transportation is $170 \mathrm{~km}$.

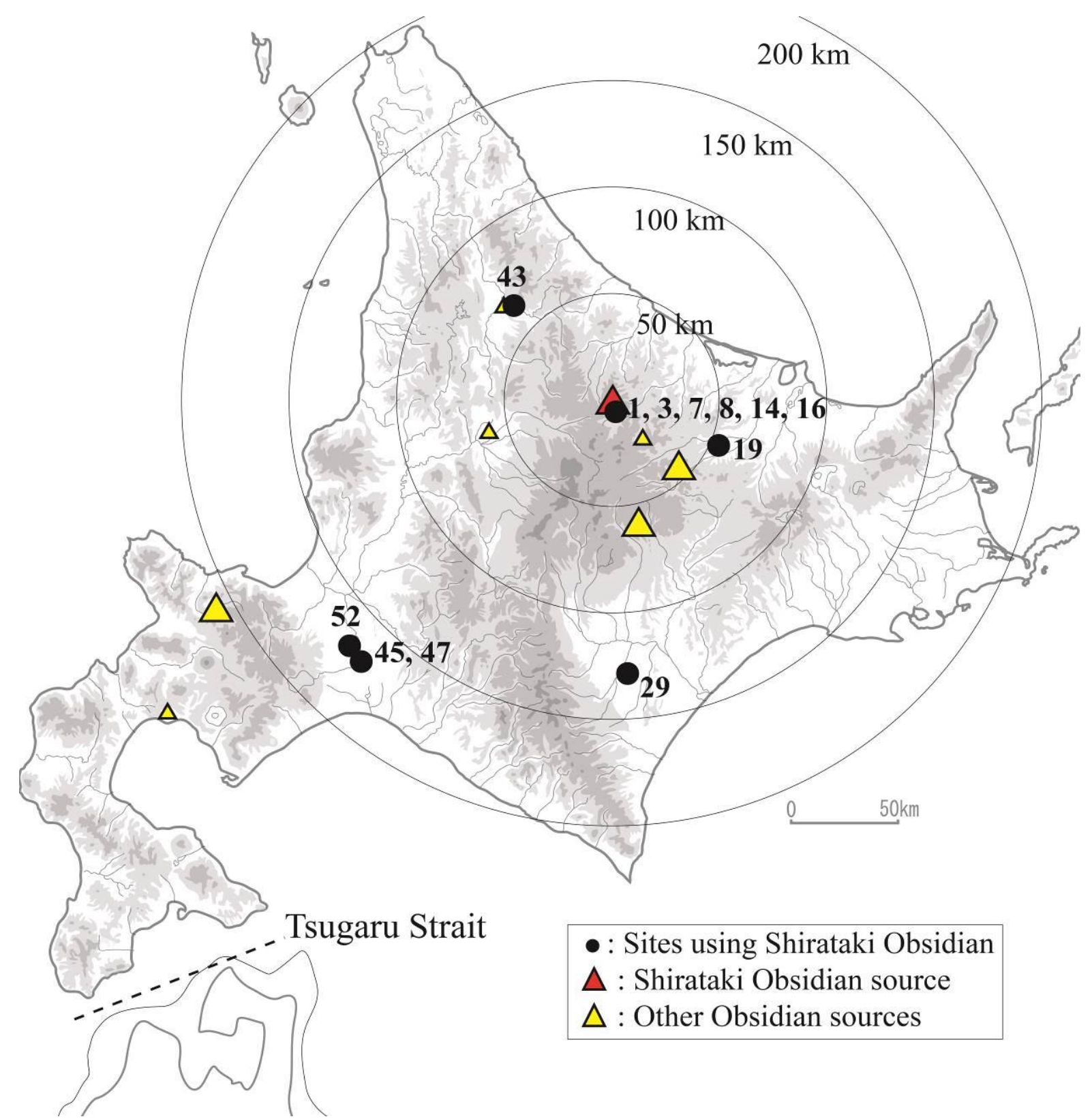

Figure 4. Distribution of Shirataki Obsidian in the Early Upper Paleolithic

\subsection{The Late Upper Paleolithic (25-10 ka cal BP)}

\subsubsection{Stage1 (early Early microblade industry) (25-21 ka cal BP)}

Stage 1 industries include the Pirika type, Tougeshita type, and Rankoshi type microblade industries (Figure 5). From this stage, people with microblade technology came into Hokkaido via Sakhalin, and this migration might signify refuge to the south caused by the 
severe cold climate of the Last Glacial Maximum. The characteristics of this stage are not only the small number of sites but also the scarcity of tools yielded from each site. The distribution of Shirataki obsidian was limited to the near vicinity of the Shirataki source and greatly reducing the distribution area. The longest distance of transportation is $60 \mathrm{~km}$.

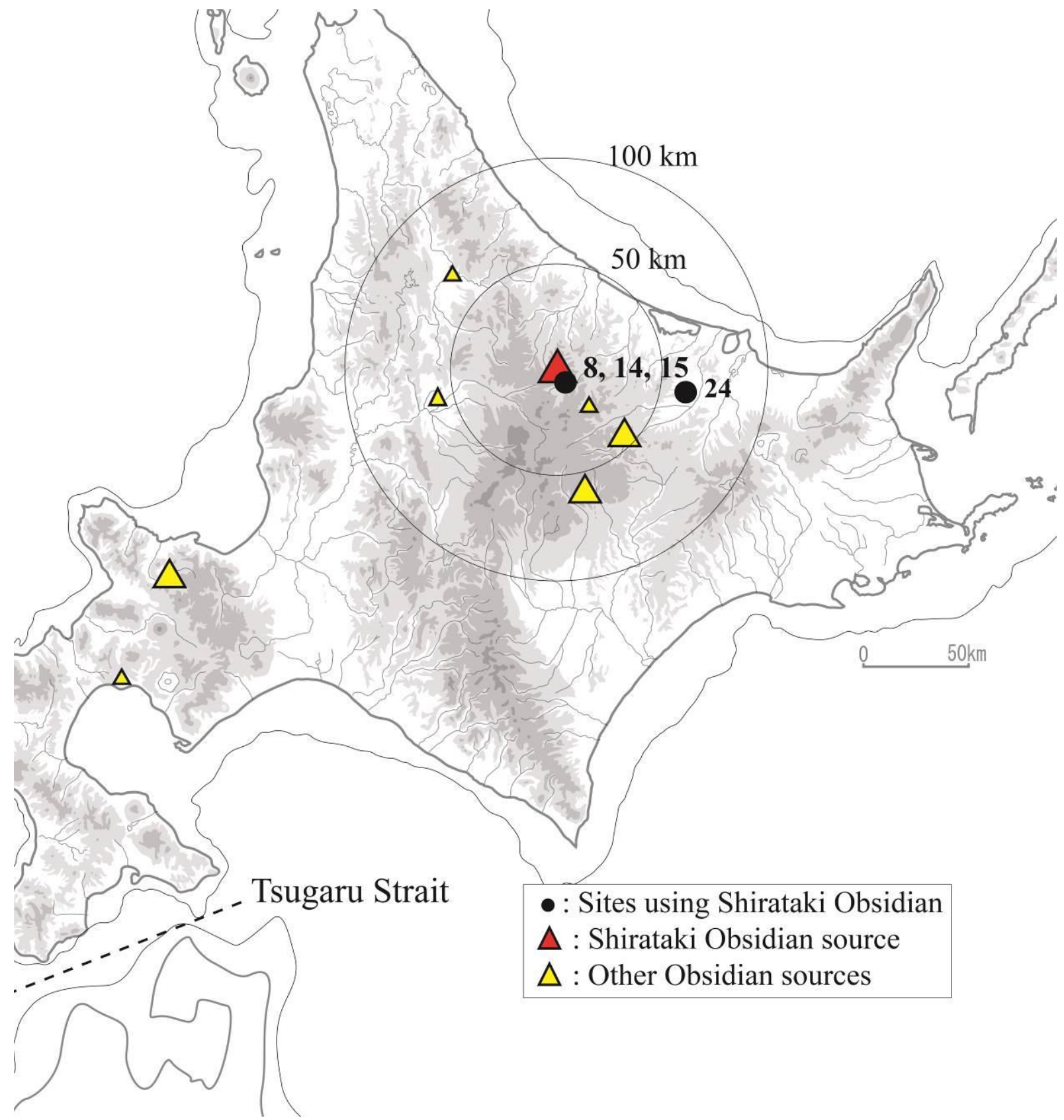

Figure 5. Distribution of Shirataki obsidian in the early Early microblade industries

\subsubsection{Stage 2 (late Early microblade industry) (19-16ka cal BP)}

Stage 2 industries include the Sakkotsu type and Tougeshita 2 type microblade industries (Figure 6). The Sakkotsu type microblade industry belongs to the real Yubetsu method, and is widely distributed in Northeast Asian (Sato 2010). In this stage, the number of sites dramatically increased, and Shirataki obsidian was transported to distant areas. In particular, the transportation of Shirataki obsidian outside of Hokkaido started around this time. The longest distance of transportation is $380 \mathrm{~km}$. 


\subsubsection{Stage 3 (Late microblade industry) (16-10ka cal BP)}

In Stage 3, we focus on each of the microblade industries separately, because they have different tendencies of obsidian usage.

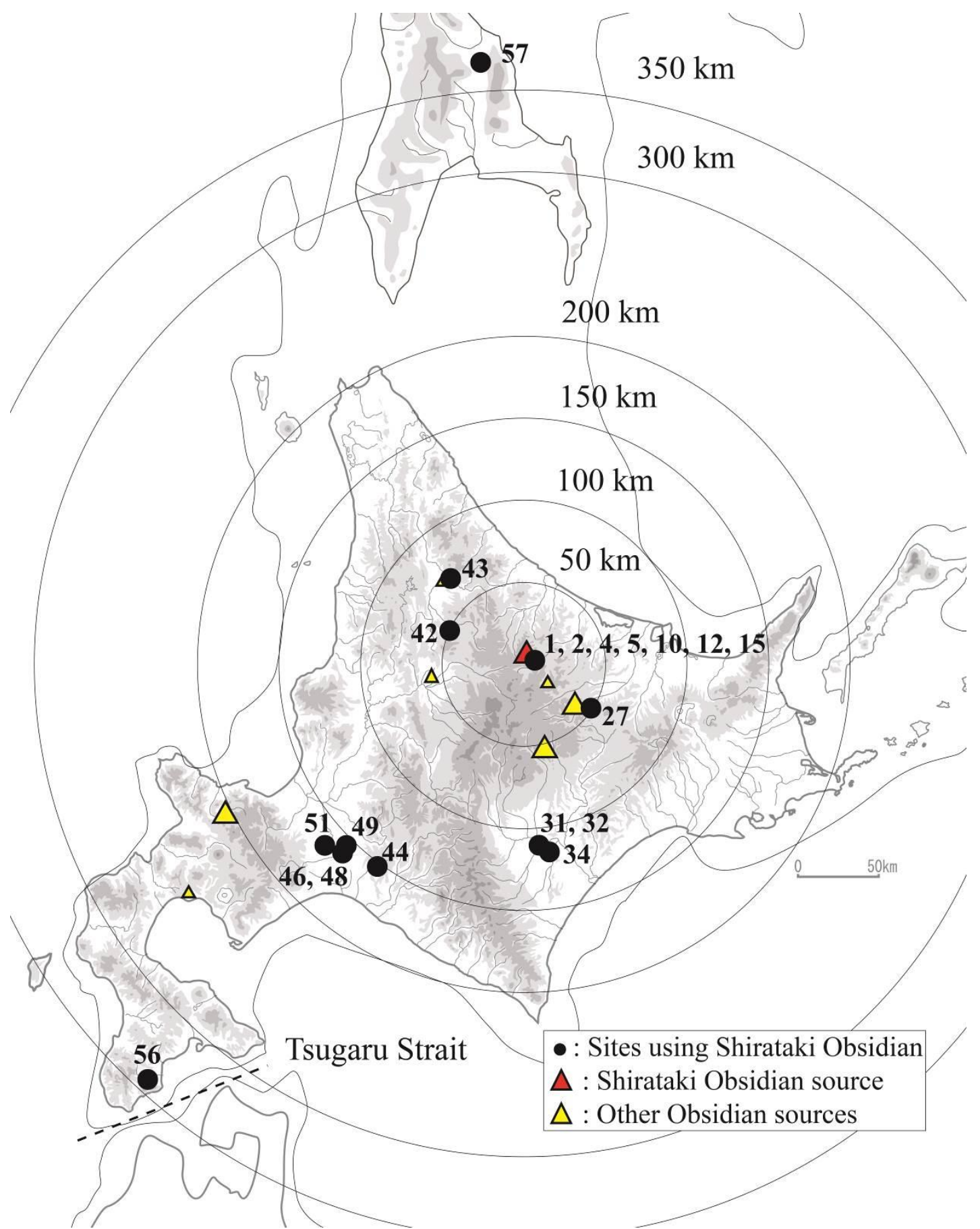

Figure 6. Distribution of Shirataki obsidian in the late Early microblade industries

\subsubsection{Shirataki type microblade industry}

The Shirataki type microblade industry (Figure 7) is included in the real Yubetsu method and widely distributed beyond Hokkaido, similar to the Sakkotsu type microblade industry of the previous stage. In this stage, Shirataki obsidian was found from the Yunohana site (Tateishi et al. 2012) in the Tohoku region, in the northern part of Honshu Island. This is the only example of Shirataki obsidian transported onto Paleo-Honshu Island in the Upper 
Paleolithic Period. This is important, because they transported Shirataki obsidian from Hokkaido to Paleo-Honshu Island across the Tsugaru Strait, and this implies the existence of seafaring in the Paleolithic period. The longest distance of transportation is about $700 \mathrm{~km}$.

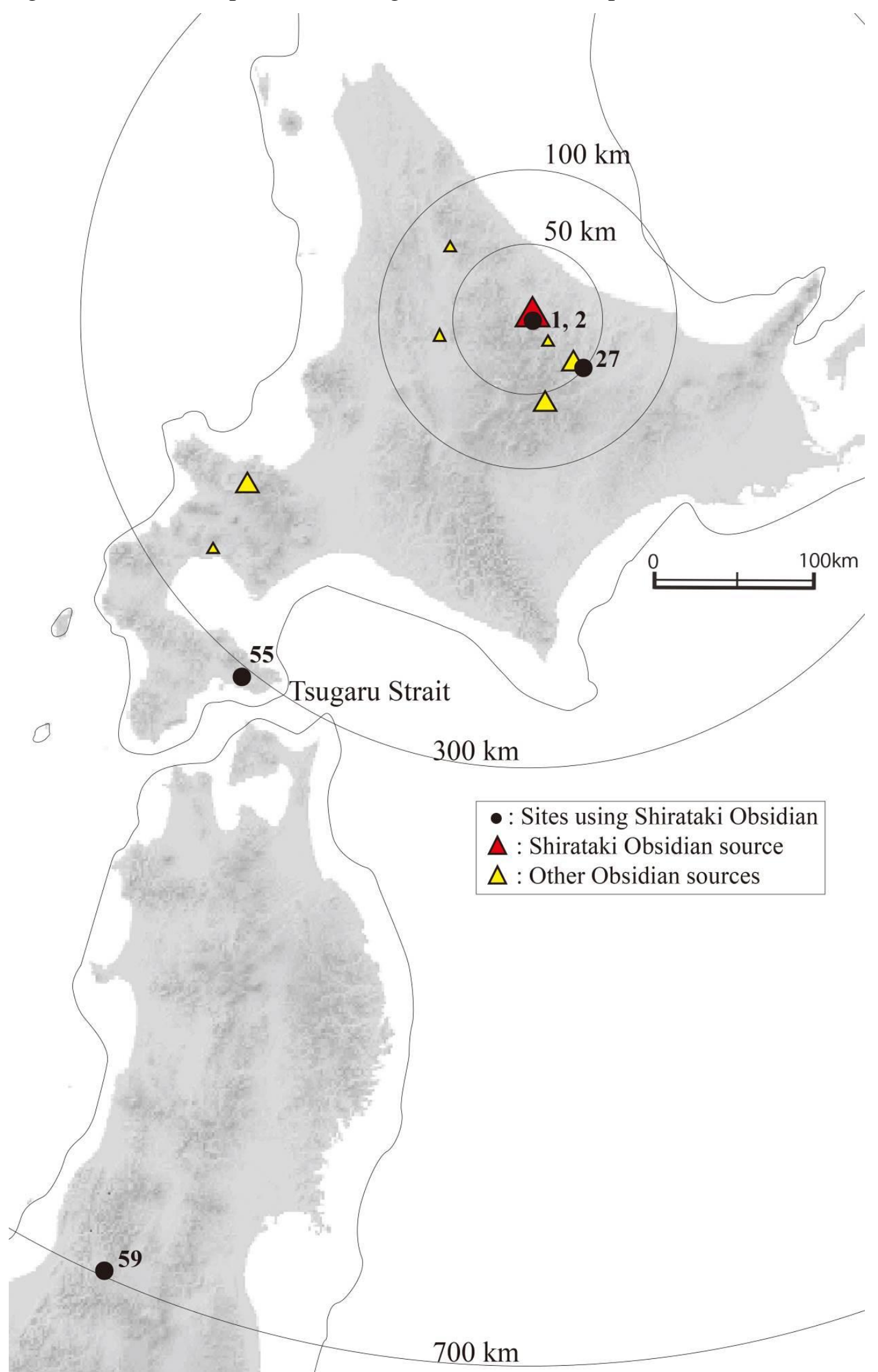

Figure 7. Distribution of Shirataki obsidian in the late microblade industry: Shirataki microblade industry 


\subsubsection{Oshorokko type microblade industry}

In the Oshorokko type microblade industry (Figure 8), Shirataki obsidian was not transported outside Hokkaido, and the distribution range is relatively smaller than other industries. The longest distance of transportation is $120 \mathrm{~km}$.

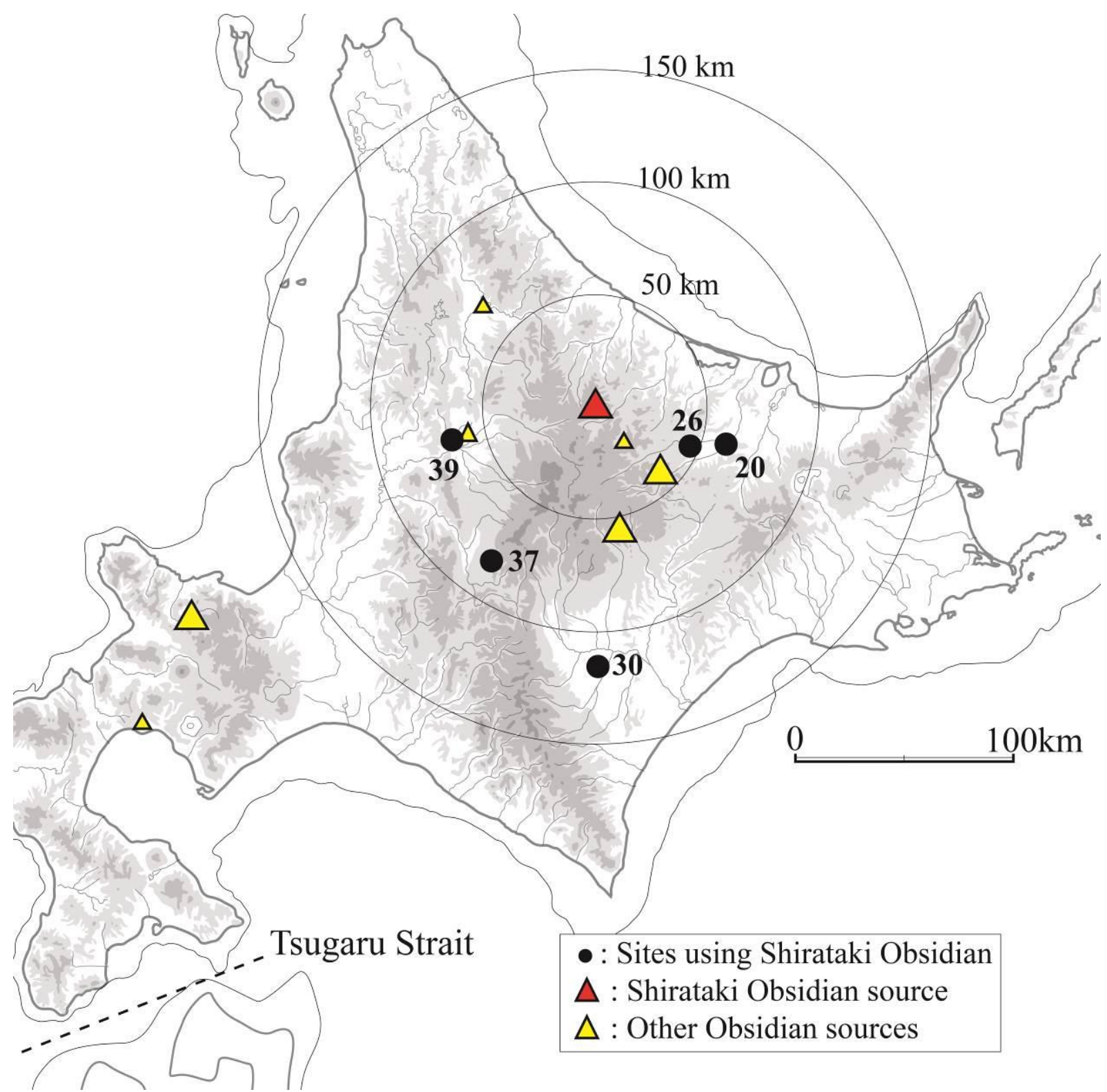

Figure 8. Distribution of Shirataki obsidian in the late microblade industry: Oshorokko type microblade industry

\subsubsection{Small boat shaped tool industry}

This industry (Figure 9) is characterized by wide distribution of Shirataki obsidian, unlike the Oshorokko type microblade industry. Ogonki 5 site, in southern Sakhalin is included in this industry, and artifacts made by Shirataki obsidian have been found from this site (Kuzmin et al. 2002, Vasilevsky 2003). The longest distance of transportation is $320 \mathrm{~km}$. 


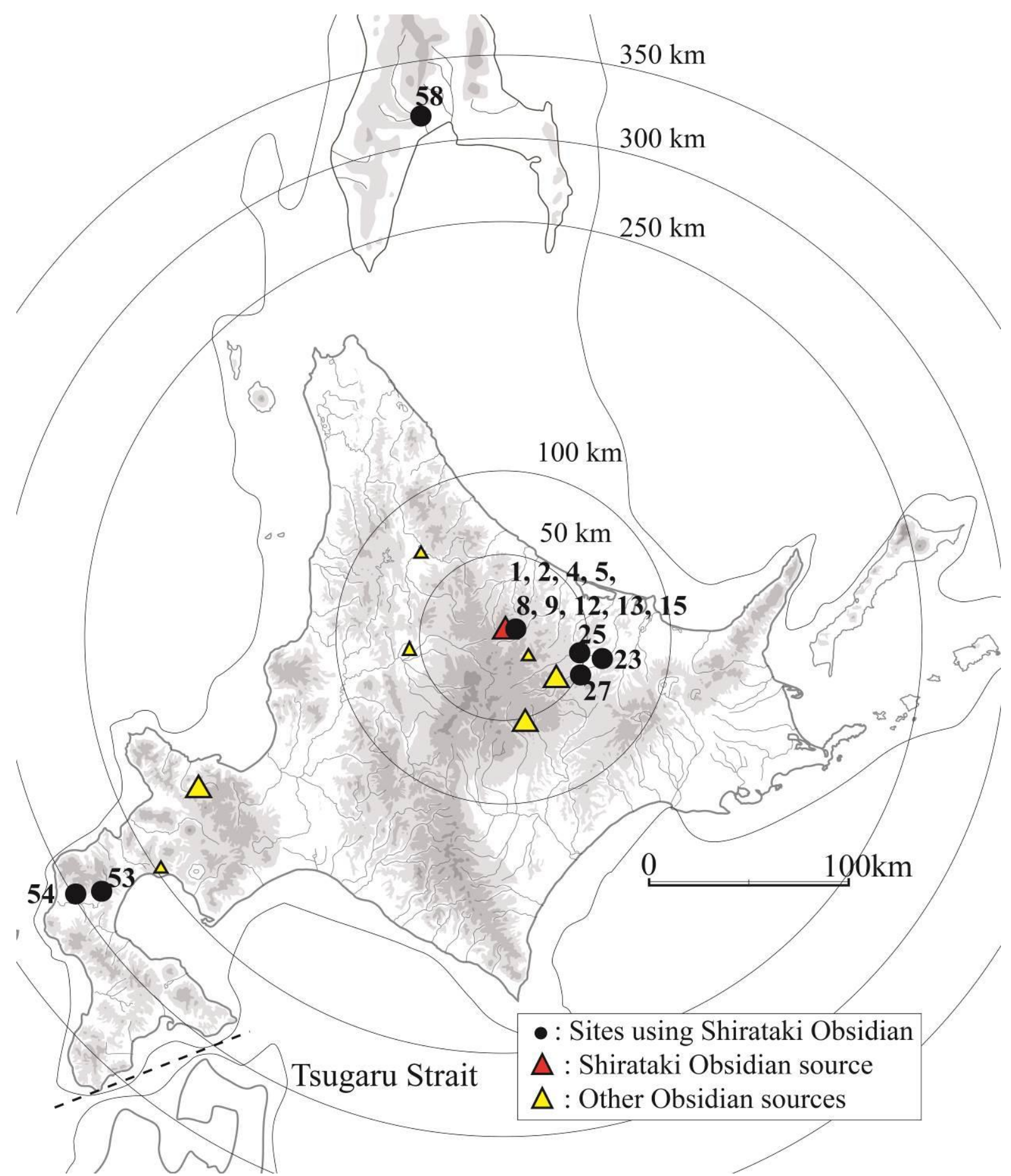

Figure 9. Distribution of Shirataki obsidian in the late microblade industry: Small boat-shaped tool industry

\subsubsection{Point and stemmed point industry}

The point and stemmed point industry (Figure 10) dates to the end of the Late Upper Paleolithic period. In that same period, pottery use commenced in Honshu and the south, signaling the beginning of the Jomon Period. In this industry, Shirataki obsidian was transported more widely than in the other stages. For example, Shirataki obsidian has been found from the Kosegasawa site (Warashina \& Oguma 2003), an Initial Jomon Period site on Honshu Island. The longest distance of transportation is $750 \mathrm{~km}$.

Hereafter, obsidian from Hokkaido was widely transported into both the northern part of Honshu Island and onto Sakhalin Island. 


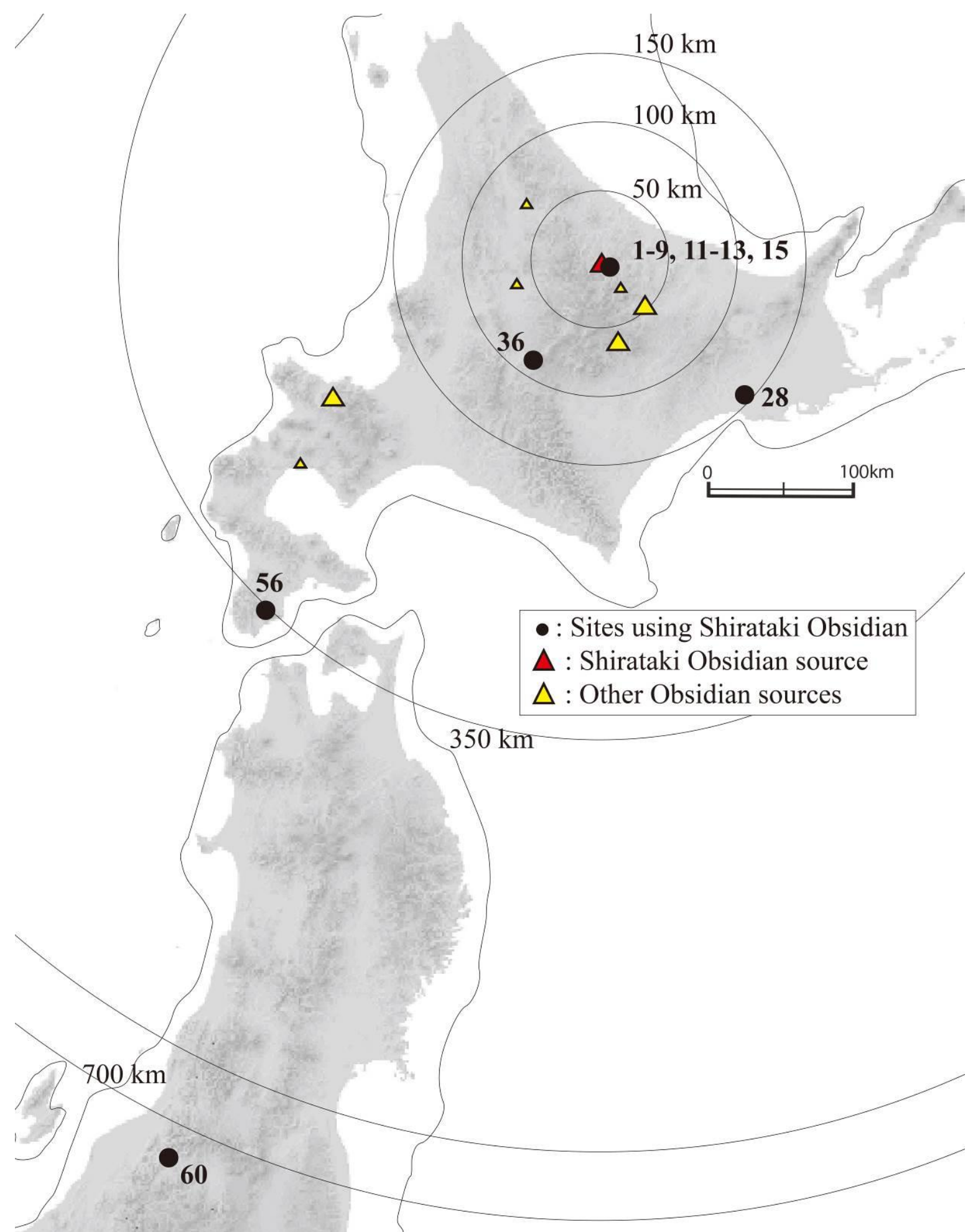

Figure 10. Distribution of Shirataki obsidian in the late microblade industry: Point and stemmed point industry

\section{Discussion}

We point out three results from our analysis.

First, the longest distance of Shirataki obsidian transportation differs in each period and industry.

Secondly, the Sakkotsu type and Shirataki type of the real Yubetsu method are characterized by dramatic expansion of distribution areas. This tendency implies that the change of obsidian distribution did not coincide with the start of Stage 1, when microblade 
technology first emerged. Moreover, the transportation of Shirataki obsidian beyond the Tsugaru Strait implies the existence of seafaring.

Thirdly, in Stage 3, not all industries show wide distribution. At the end of Stage 3 in the point and stemmed point industry, the distribution area of Shirataki obsidian expanded again. After that, Shirataki obsidian came to be regularly transported to the northern end of Honshu Island in the Jomon Period as well as Sakhalin Island and the northeastern part of the continent (Kuzmin et al. 2002).

Since Naoe's (2009) argument on the procurement and the distribution of Shirataki obsidian, obsidian source analysis data was compiled, and we were able to confirm that our analysis results did not contradict his results.

We focus on the second point, the problem of the real Yubetsu industry.

Figure 11 shows obsidian source composition of Sakkotsu type microblade cores and Tougeshita type microblade cores. This graph implies that Sakkotsu type microblade cores are usually made from Shirataki obsidian. Tougeshita 2 type microblade cores, however, were made from obsidian of various sources. Consequently, real Yubetsu microblade cores had strong ties with Shirataki obsidian. Most of the Sakkotsu type microblade cores and the entire Sakkotsu type microblade industry requires large nodules of high quality, therefore Shirataki was the most suitable source for such raw materials (Yamada 2006). On the other hand, in the Tougeshita 2 type microblade industry, they used round pebbles and small debris or angular nodules in addition to large raw materials, thus we can presume that they used a variety of local raw materials in areas where high quality large obsidian nodules were relatively scarce. Furthermore, our results are consistent with the hypothesis of Kimura (1995) that Sakkotsu type microblade cores were transported over a long distance, uniting them with the Shirataki obsidian, whereas the Tougeshita type microblade cores were made of obsidian available in the vicinity of the sites. The background of this expansion is behaviorally considered to be one characterized with a long distance mobility strategy of the real Yubetsu microblade industry supported by the abundance and the large size of Shirataki obsidian. In addition, transportation of over $700 \mathrm{~km}$ cannot be explained thoroughly enough by direct procurement, so we would expect the existence of some sort of exchange network.
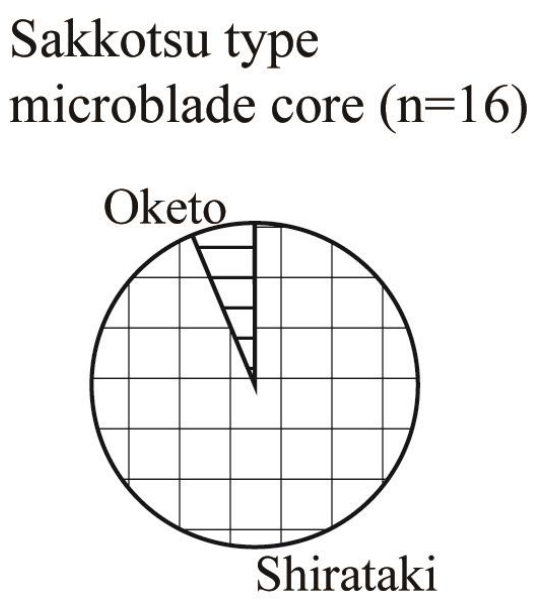

\section{Tougeshita 2 type microblade core $(n=44)$}

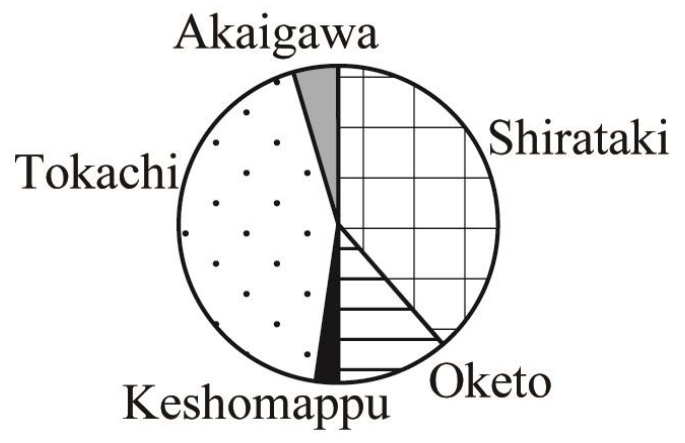

Figure 11. Ratio of obsidian sources in Sakkotsu type and Tougeshita2 type microblade cores

\section{Conclusion}

To conclude, we summarize with three points:

First, the distribution area of Shirataki obsidian basically expanded through the Upper Paleolithic Period, but it shows complex episodes of expansion and reduction in each stage and industry. 
Second, the drastic expansion of the Shirataki obsidian distribution area did not coincide with the introduction of microblade technology. Rather, the drastic expansion of the Shirataki obsidian distribution area coincide with the next stage of the introduction of microblade technology, that is, the adoption of real Yubetsu industry began in the beginning of Stage 2 .

Third, at the end of Stage 3, the distribution area of Shirataki obsidian expanded again in the point and stemmed point industry, and subsequently, Shirataki obsidian came to be regularly transported to the northern end of Honshu Island in the Jomon Period.

\section{Acknowledgement}

We are grateful to Prof. Masami Izuho, Drs. Yo Negishi and Satoru Yamada, and Mr. Daigo Natsuki for their support and helpful comments on this paper. We would also like to thank Prof. Keiji Wada for allowing us to use the EPMA measuring data of obsidian materials from the Kamihoronaimoi, Momijiyama, and Yoshiizawa sites.

\section{Notes}

1. More materials made from Shirataki obsidian were reported in Sakhalin (Kuzmin et al. 2002), but we did not deal with them in this paper as we are not yet aware of which were analyzed or what industry they belong to apart from the Sokol and Ogonki 5 sites.

\section{References}

Higashimura, T., \& Warashina, T. 1995, 帯広市宮本遺跡他出土の黒曜石製遺物の原材産 地分析. In: 宮本遺跡 2, (Kitazawa, M. et al., Eds.), Obihiro city board of education, Obihiro: p. 65-74. (in Japanese) ("obsidian source analysis of materials from Miyamoto site and others, Obihiro, Hokkaido").

Ibutsu Zairyo Kenkyujo, 2007, 白滝 8 遺跡 • 白滝 18 遺跡 - 白滝 3 遺跡出土の黒曜石製 石器の原材産地分析・水和層測定. In: 白潼遺跡群 VIII, (Suzuki, H. \& Naoe, Y. Eds.), Hokkaido Archaeological Operations Center, Ebetsu: p. 261-285. (in Japanese) ("Source identification analysis and measurement of obsidian hydration layers for obsidian lithic artefacts recovered from Shirataki8 site $\cdot$ Shirataki18 site $\cdot$ Shirataki3 site, Hokkaido").

Ibutsu Zairyo Kenkyujo, 2008, 旧白滝 5 遺跡出土の黒曜石製石器の原材産地分析・水和 層測定. In: 白滝遺跡群 IX, (Naoe, Y., Ed.), Hokkaido Archaeological Operations Center, Ebetsu: p. 211-230. (in Japanese) ("Source identification analysis and measurement of obsidian hydration Layers for obsidian lithic artefacts recovered from Kyushirataki5 site, Hokkaido").

Ibutsu Zairyo Kenkyujo, 2009, 遠軽町旧白滝 16 遺跡出土の黒曜石製遺物の原材産地分 析, In: 白滝遺跡群 X, (Naoe, Y. Ed.), Hokkaido Archaeological Operations Center, Ebetsu: p. 239-251. (in Japanese) (“Obsidian source analysis of materials from Kyushirataki16 site, Engaru town, Hokkaido").

Ibutsu Zairyo Kenkyujo, 2010, 川東 16 遺跡出土の黒曜石製遺物の原産地分析. In: 蘭国 橋遺跡・ 川東 16 遺跡, (Ota, T., et al. Eds.), Kitami city board of education, Kitami: p. 280-329. (in Japanese) ("Source identification analysis for obsidian lithic artifacts recovered from Kawahigashi16 site, Hokkaido"). 
Ibutsu Zairyo Kenkyujo, 2011a, 北見市北上 4 遺跡出土の黒曜石製遺物の原材産地分析. In: 北上 4 遺跡, (Kumagai, H., \& Tanishima, Y. Eds.), Hokkaido Archaeological Operations Center, Ebetsu: p. 218-232. (in Japanese) ("Source identification analysis for obsidian lithic artifacts recovered from Kitakami4 site, Kitami city, Hokkaido").

Ibutsu Zairyo Kenkyujo, 2011b, ホロカ沢 I 遺跡出土の黒曜石製遺物の原材産地分析. In: 白滝遺跡群XI, (Sakamoto, T., Ed.), Hokkaido Archaeological Operations Center, Ebetsu: p. 347-364. (in Japanese) ("Source identification analysis for obsidian lithic artifacts recovered from HorokazawaI site").

Ibutsu Zairyo Kenkyujo, 2011c, 北見市川東 3 遺跡出土の黒曜石製遺物の原材産地分析. In: 川向 23 - 川東 13 遺跡, (Ota, T. et al. Eds.), Kitami city board of education, Kitami: p. 321-349. (in Japanese) ("Source identification analysis for obsidian lithic artifacts recovered from Kawahigashi3 site, Kitami city").

Ibutsu Zairyo Kenkyujo, 2012a, 遠軽町旧白滝 15 遺跡出土の黒曜石製遺物の原材産地分 析. In: 白滝遺跡群 XII, (Naoe, Y., Ed.), Hokkaido Archaeological Operations Center, Ebetsu: p. 529-546. (in Japanese) (“Obsidian source analysis of materials from Kyushirataki15 site, Engaru town, Hokkaido").

Inoue, I., 2003, 白滝第 30 地点遺跡出土黒曜石遺物の化学分析. In: 白滝第 30 地点遺跡, (Matsumura, Y., \& Seshimo, N., Eds.), Shirataki-Mura Board of Education, Engaru: p. 245-258. (in Japanese) ("Chemical composition of obsidian stone tools from the locality 30 of Shirataki site, Hokkaido").

Izuho, M., \& Hirose, W., 2010, A Review of Archaeological Obsidian Studies on Hokkaido Island (Japan). In: Crossing the Straits: Prehistoric Obsidian Source Exploitation in the Pacific Rim, (Kuzmin, Y.V., \& M.D. Glascock, Eds.), BAR International Series Vol. 2152, Archaeopress, Oxford: p. 9-25.

Izuho, M., Hirose, W., \& Sato, H., 2008, 北海道における考古学的黒曜石研究の現状と課 題. 旧石器研究, 4: 107-122. (in Japanese) (“A review of the archaeological obsidian study in Hokkaido, Japan")

Izuho, M., \& Sato, H., 2007, Archaeological Obsidian Study in Hokkaido, Japan: Retrospect and Prospect. Indo-Pacific Prehistory Association Bulletin, 27: 114-121. URL: http://ejournal.anu.edu.au/index.php/bippa/article/view/41

Japanese Paleolithic Research Association, 2010, 日本列島の旧石器時代遺跡日本旧石器

(先土器・岩宿) 時代遺跡のデータベース, Japanese Paleolithic Research Association ed., Tokyo, 377 p. (in Japanese) ("Palaeolithic Sites in the Japanese Islands: A Database").

Kannari, T., \& Sugihara, S., 2006, 元町 2 遺跡・みどり 1 遺跡・豊岡 7 遺跡出土黒曜石 製遺物の産地推定. 美幌博物館研究報告, 14: 1-20, Bihoro Museum, Bihoro. (in Japanese) ("The obsidian source analysis of obsidian artifacts at Motomachi 2, Midori 1 and Toyooka7 sites in Bihoro, Hokkaido").

Kimura, H., 1995, 黒曜石・ヒト・技術. 北海道考古学, 31: 3-63. (in Japanese) ("Obsidian, human, and technology"). 
Kondo, Y., \& Warashina, T., 1998b, 千歳市オサツ 16 遺跡出土の黒曜石石器・剥片の産 地分析と水和層年代. In: オサツ16 遺跡(3), (Oshima, H., Ed.), Hokkaido Bunkazai Hogo Kyokai, Sapporo: p. 245-247. (in Japanese) ("Source identification analysis and obsidian hydration dating for obsidian lithic tools and flakes recovered from Osatsu16 site, Chitose city")

Koshimizu. S., 1981, 石狩低地帯に出土する黒曜石片の原産地. 地球科学, 35(6): 67273. (in Japanese) ("Source areas of obsidian found in the prehistoric sites in the Ishikari-Tomakomai Low-land area in Hokkaido, Japan”).

Koshimizu, S., 1988a, 名寄市黒曜石の年代および名寄市日進 2 遺跡出土黒曜石製石器 類の原産地. In: 名寄市日進 2 遺跡, 日進 31 遺跡, (Suzuki, K., Ed.), Nayoro city board of education, Nayoro: p. 83-90. (in Japanese) ("Obsidian dating of materials from Nayoro city area and obsidian source analysis of Nisshin 2 site in Nayoro city").

Koshimizu, S., 1988b, 石川 1 遺跡出土黒曜石片の年代と原産地. In: 石川 1 遺跡, (Naganuma, T., Ed.), Hokkaido Archaeological Operations Center, Ebetsu: p. 261-264, (in Japanese) ("dating and source analysis of obsidian flakes from Ishikawa1 site").

Koshimizu, S., 1990, 黒曜石の原産地同定およびフィッション・トラック年代測定. In: 神丘 2 遺跡，（Terasaki, Y. Ed.), Imakane town board of education, Imakane: p. 118119. (in Japanese) (“Obsidian source identification and fission-track dating”).

Koshimizu, S., 1994, 北斗遺跡出土黒曜石片の水和層年代. In: 釧路市北斗遺跡 $I V$, (Matsuda, T., Ed.), Kushiro city board of education, Kushiro: p. 39-40. (in Japanese) ("Obsidian hydration dating of obsidian fragments from Hokuto site").

Kuzmin, Y.V., M.D. Glascock, \& H. Sato, 2002, Sources of archaeological obsidian on Sakhalin Island (Russian Far East). Journal of Archaeological Science, 29: 741-749. doi: $\underline{10.1006 / j a s c .2001 .0748}$

Kuzmin, Y.V., \& M.D. Glascock (Eds.) 2010, Crossing the Straits: Prehistoric Obsidian Source Exploitation in the North Pacific Rim. BAR International Series Vol. 2152, Archaeopress, Oxford. 227 p.

Kuzmin, Y.V., \& V.K. Popov (Eds.) 2000, Volvanic Glasses of the Russian Far East: Geological and Archaeological Aspects. Geological Institute, Far eastern Branch of the Russian Academy of Sciences, Vladivostok. 168 p.

Meiji Daigaku Kobunkazai Kenkyujyo (Ed.), 2009, 蛍光 $X$ 線分析装置による黒曜石製遺 物の原産地推定一基礎データ集〈1〉-, Research Laboratory of Cultural Properties, Meiji University, Meiji University, Tokyo: 294 p. (in Japanese) (“Geological source identification of obsidian artefacts by X-ray fluorescence analysis: a database 1”).

Meiji Daigaku Kobunkazai Kenkyujyo (Ed.), 2011, 蛍光X 線分析装置による黒曜石製遺 物の原産地推定一基礎データ集〈2〉-, Research Laboratory of Cultural Properties, Meiji University, Tokyo: 294 p. (in Japanese) ("Geological source identification of obsidian artefacts by X-ray fluorescence analysis: a database 2").

Nakatani, Y., \& Wada, K., 2010, 後期旧石器時代、旭川市共栄 7 遺跡の剥片石器とその 石材原産地,. 北海道教育大学大雪山自然教育施設研究報告, 44: 7-16, Asahikawa. (in Japanese) ("The flaked-stone artifacts and their obsidian source at the upper Paleolithic site of Kyoei-7, Asahikawa city, northern Hokkaido"). 
Naoe, Y., 2009, 白滝産黒曜石の獲得とその広がり. 旧石器研究, 5: 11-22, Japanese Paleolithic Research Association. (in Japanese) ("Procurement of Obsidian in Shirataki Region and Its Distribution").

Sato, H., 2004, Prehistoric obsidian exploitation in the Russian Far East. In: Obsidian and Its Use in Stone Age of East Asia, (Anbiru, M., Ed.), Meiji University Centre for Obsidian and Lithic Studies, Nagano: p. 43-51.

Sato, H., 2010, 東アジアにおける削片系細石刃石器群の伝播. In: 比較考古学の新地平, (Kikuchi, T., Ed.), Doseisha, Tokyo: p. 895-904. (in Japanese) ("Diffusion of the microblade industries with spalling technique in Eastern Asia").

Sato, H., 2011a, Did the Japanese obsidian reach the continental Russian Far East in Upper Paleolithic? In: Emlékkö Violának: Papers in honour of Viola T. Dobosi, (T.B. Katalin \& M. András, Eds.), Hungarian National Museum, Budapest: p. 206-223.

Sato, H. (Ed.) 2011b, 環日本海北部地域における後期更新世の環境変動と人間の相互作 用に関する総合的研究, Department of Archaeology, Graduate School of Humanities and Sociology, The University of Tokyo, Research Institute for Humanity and Nature, Kitami. 261 p. (in Japanese) ("Research on the Relationship between Human and Environmenal fluctuation in the Northern Circum Japan Sea Area (NCJSA) in Late Pleistocene").

Sato, H., \& Yakushige, M.. in press, Obsidian exploitation and circulation in late Pleistocene Hokkaido in The northern Part of the Japanese archipelago. In: Lithic raw material exploitation and circulation in Prehistory. A comparative perspective in diverse palaeoenvironments. ERAUL vol. 138 (M. Yamada \& A. Ono, Eds.), Université de Liège, Liège.

Sugihara, S., Kannari, T., Shibata, T., \& Nagai, M., 2009, 北海道、置戸安住遺跡出土黒曜 石製遺物の原産地推定. 旧石器研究, 5: 131-150. (in Japanese) (“Sources of Obsidian Artifacts from the Oketo-Azumi Site in Hokkaido, Japan: On the Viewpoints of Petrography and Geochemistry Analysis").

Takehara, H., 2008, キウス 9 遺跡出土黒曜石の産地同定. In: 千歳市キウス 9 遺跡, (Miura, M., et al. Eds.), Hokkaido Archaeological Operations Center, Ebetsu: p. 340343. (in Japanese) ("Source identification analysis for obsidian recovered from Kiusu 9 site").

Takehara, H., 2010, アンカリトー7 遺跡出土黒曜石の産地推定. In: 千歳市アンカリトー 7 遺跡、アンカリトー9 遺跡, (Miura, M., et al. Eds.), Hokkaido Archaeological Operations Center, Ebetsu: p. 277-279, (in Japanese) ("Source identification analysis for obsidian recovered from Ankarito7 site").

Takehara, H., 2013, 祝梅川上田遺跡出土黒曜石の産地推定(平成 20 年度). In: 千歳市祝 梅川上田遺跡(2), (Miura, M., et al. Eds.), Hokkaido Archaeological Operations Center, ed., Ebetsu: p. 382-384. (in Japanese) ("Source identification analysis for obsidian recovered from Shukubaigawaueda site"). 
Tateishi, T., Kato, M., Shibuya, T., Aita, Y., Kosuge, M., \& Ninomiya, S., 2012, 山形県湯の 花遺跡・群馬県稲荷山 V 遺跡出土黒曜石資料の産地分析. In: 北関東地方の細石 刃文化, abstract for Iwajuku forum2012, Iwajuku forum Executive Committee eds., Iwajhuku Museum, Kasakake: p. 90-94. (in Japanese) ("Obsidian source analysis of materials from Yunohana site, Yamagata prefecture and InariyamaV site, Gunma prefecture").

Toyohara, T., \& Sakai, K., 2011, 安住遺跡（置戸町）出土の石器. 釧路川20:1-4. (in Japanese) ("Lithic artifacts recovered from Azumi site, Oketo town").

Vasilevsky, A. A., 2003, Periodization and classification of the Upper Paleolithic of Sakhalin and Hokkaido in the light of the research conducted at the Ogonki-5 site. Archaeology, Ethnology and Anthropology of Eurasia, 3(15): 51-69.

Wada, K., \& Sano, K., 2011, 白滝黒曜石の化学組成と微細組織. 旧石器研究, 7: 57-73. (in Japanese) ("Chemical composition and microstructure of the Shirataki obsidian, northern Hokkaido: geological and petrological source data for the precise obsidian source identification")

Warashina, T., 1993, 帯広市落合、上似平、暁、空港南 A 遺跡出土の黒曜石製遺物の 原材産地分析。帯広百年記念館紀要, 11: 7-16. (in Japanese) (“Source identification analysis for obsidian lithic artefacts recovered from Ochiai, Kamiiitaira, Akatsuki and Kukominami A sites, Obihiro-shi”).

Warashina, T., 1997a, 帯広市稲田 1 遺跡他出土の黒曜石製遺物の原材産地分析. In: 帯 広・稲田 1 遺跡, （Kitazawa, M. \& Yamahara, T., Eds.), Obihiro city board of education, Obihiro: p. 81-89. (in Japanese) ("Source identification analysis for obsidian lithic artifacts recovered from Inada1 site, Obihiro city").

Warashina, T., 1997b, 千歳市オサツ 16 遺跡出土の黒曜石製遺物の原材産地分析. In: 千 歳市オサツ16 遺跡(2), (Oshima, H., Ed.), Hokkaido Bunkazai Hogo Kyokai, Sapporo: p. 422-426. (in Japanese) ("Source identification analysis for obsidian artifacts recovered from Osatsu16 site, Chitose city").

Warashina, T., 1998, 黒曜石・安山岩製遺物の原材産地分析. In: 北進遺跡 II , (Ota, T., Ed.), Kitami city board of education, Kitami: p. 27-38. (in Japanese) ("Source identification analysis of lithic artifacts made by obsidian and andesite").

Warashina, T., 1999a, 落合遺跡出土の黒曜石製遺物の原材産地分析および黒曜石製遺 物の非破壊分析による水和層の測定. In: 帯広・落合遺跡 2, (Yamahara, T., Ed.), Obihiro city board of education, Obihiro: p. 63-70. (in Japanese) (“Source identification analysis and measurement of obsidian hydration layers by non-destructive method for obsidian lithic artifacts recovered from Ochiai site, Obihiro city").

Warashina, T., 1999b, 柏台 1 遺跡出土の黒曜石製遺物の原材産地分析および黒曜石製 遺物の非破壊分析による水和層年代の測定. In: 柏台 1 遺跡, (Fukui, J., \& Koshida, K. Eds.), Hokkaido Archaeological Operations Center, Ebetsu: p. 211-224. (in Japanese) ("Source identification analysis of obsidian lithic artifact from Kahiwadai1 site and obsidian hydration dating by non-destructive method"). 
Warashina, T., 1999c, ユカンボシ C15 遺跡出土の黒曜石製遺物の原材産地分析および 黒曜石製遺物の非破壊分析による水和層の測定. In: ユカンボシC15 (2), (Nishida, S., et al. Eds.), Hokkaido Archaeological Operations Center, Ebetsu: p. 474-483. (in Japanese) ("Source identification analysis and measurement of obsidian hydration layers by non-destructive method for obsidian lithic artifacts recovered from YukanboshiC15 site").

Warashina, T., 2000a, 上白滝 7 遺跡出土の黒曜石製石器の原材産地分析および非破壊 分析による水和層の測定. In: 白滝遺跡群 I, (Naganuma, T., et al. Eds.), Hokkaido Archaeological Operations Center), Ebetsu: p. 219-233. (in Japanese) (“Source identification analysis and measurement of obsidian hydration layers by non-destructive method for obsidian lithic artifacts recovered from Kamishirataki7 site").

Warashina, T., 2000b, 芽室町北伏古 2 遺跡出土の黒曜石製石器の原材産地分析および 非破壊分析による水和層の測定. In: 北伏古 2 遺跡, （Sagawa, S., \& Kageura, S., Eds.), Hokkaido Archaeological Operations Center, Ebetsu: p. 31-40.(in Japanese) ("Source identification analysis and measurement of obsidian hydration layers by nondestructive method for obsidian lithic artifacts recovered from Kitafushiko2 site, Memuro cho").

Warashina, T., 2000c, 東町遺跡出土の黒曜石製石器の原材産地分析および非破壊分析 による水和層の測定. In: 東町遺跡, (Kumagai, H., et al. Eds.), Hokkaido Archaeological Operations Center, Ebetsu: p. 67-77. (in Japanese) (“Source identification analysis and measurement of obsidian hydration layers by non-destructive method for obsidian lithic artifacts recovered from Higashimachi site").

Warashina. T., 2001, 上白滝 2 ・上白滝 6 - 北支湧別 4 遺跡出土の黒曜石製石器の原材 産地および非破壊分析による水和層の測定. In: 白滝遺跡群 II , (Naganuma, T., et al. Eds.), Hokkaido Archaeological Operations Center, Ebetsu: p. 235-247. (in Japanese) ("Source identification analysis and measurement of obsidian hydration layers by non-destructive method for obsidian lithic artifacts recovered from Kamishirataki2 site - Kamishirataki6 site - Kitashiyubetsu4 site").

Warashina. T., 2002a, 自然科学的分析等 奥白滝 1 ・ 上白滝 5 - 北支湧別 4 遺跡出土の 黒曜石製石器の原材産地分析および非破壊分析による水和層の推定. In: 白滝遺 跡群III , (Naganuma, T., et al. Eds.), Hokkaido Archaeological Operations Center, Ebetsu: p. 295-316. (in Japanese) ("Source identification analysis and measurement of obsidian hydration layers by non-destructive method for obsidian lithic artifacts recovered from Okushirataki1 site $\cdot$ Kamishirataki5 site $\cdot$ Kitashiyubetsu4 site").

Warashina, T., 2002b, 上似平遺跡出土の旧石器時代黒曜石細石刃、石片の原材産地分 析. 帯広百年記念館紀要, 20: 43-52. (in Japanese) (“The source of the raw materials by XRF analysis in obsidian micro-blades and flakes from Kamiitaira site").

Warashina, T., 2002c, 落合遺跡および関連遺跡出土の黒曜石製石器、石片の原材産地 分析. In: 帯広 ·落合遺跡 3 , (Yamahara, T., Ed.), Obihiro city board of education, Obihiro: p. 25-34. (in Japanese) ("Source identification analysis for obsidian lithic artifacts and fragments recovered from Ochiai site and other sites"). 
Warashina, T., 2003, オルイカ 2 遺跡出土の黒曜石製石器・剝片の原材産地分析. In: オ ルイカ 2 遺跡, (Abe, A. et al. Eds.), Hokkaido Archaeological Operations Center, Ebetsu: p. 169-178. (in Japanese) ("Source identification analysis for obsidian lithic tools and flakes recovered from Oruika2 site").

Warashina, T., 2004, 上白滝 8 ・ 上白滝 6 遺跡出土の黒曜石製石器の原材産地分析およ び非破壊分析による水和層の測定. In: 白滝遺跡群IV, (Naganuma, T., et al. Eds.), Hokkaido Archaeological Operations Center, Ebetsu: p. 298-320. (in Japanese) ("Source identification analysis and measurement of obsidian hydration layers by nondestructive method for obsidian lithic artifacts recovered from Kamishirataki8 • Kamishirataki6 site").

Warashina, T., 2006, 上白滝 8 遺跡出土の黒曜石製石器の原材産地分析・水和層測定. In: 白滝遺跡群VI, (Suzuki, H., \& Naoe, Y., Eds.), Hokkaido Archaeological Operations Center, Ebetsu: p. 283-301. (in Japanese) ("Source identification analysis and measurement of obsidian hydration layers by non-destructive method for obsidian lithic artifacts recovered from Kamishirataki8 site").

Warashina. T., 2007, 服部台 2 - 奥白滝 1 遺跡出土の黒曜石製石器の原材産地分析・水 和層測定. In: 白滝遺跡群VII, (Naoe, Y., \& Suzuki, H., Eds.), Hokkaido Archaeological Operations Center, Ebetsu: p. 275-296. (in Japanese) ("Source identification analysis and measurement of obsidian hydration Layers for obsidian lithic artefacts recovered from Hattoridai2 site • Okushirataki1 site").

Warashina, T., \& Higashimura, T., 1984, 北見市内における遺跡出土の黒曜石遺物の石材 産地分析. 北見楖土博物館紀要, 14: 1-13. (in Japanese) (“Source identification analysis for obsidian lithic artifacts recovered from sites in Kitami city").

Warashina, T., \& Higashimura, T., 1985a, 湯の里遺跡出土の黒曜石遺物の原材産地分. In: 湯の里遺跡群, (Hata, H. Ed.), Hokkaido Archaeological Operations Center, Ebetsu: p. 201-214. (in Japanese) ("Source analysis of obsidian archaeological materials from Yunosato site").

Warashina, T., \& Higashimura, T., 1985b, 美利河 1 遺跡出土の黒曜石遺物の原材産地分 析. In: 美利河 1 遺跡, (Naganuma, T., et al. Eds.), Hokkaido Archaeological Operations Center, Ebetsu: p. 270-281. (in Japanese) ("Source identification analysis for obsidian lithic artifacts from Pirikal site").

Warashina, T., \& Higashimura, T., 1985c, 広郷 8 遺跡出土の黒曜石遺物の原材産地分析. In: 広郷 8 遺跡(II), (Miya, H., Ed.), Kitami Shiritsu Kitami Kyodo Hakubutsukan, Kitami: p. 138-144. (in Japanese) ("Source identification analysis for obsidian lithic artifacts recovered from Hirosato8 site").

Warashina, T. \& Higashimura, T., 1987a, 嵐山 2 遺跡出土の黒曜石遺物の石材産地分析. In: 嵐山 2 遺跡, (Nishida, S., et al. Eds.), Hokkaido Archaeological Operations Center, Ebetsu: p. 128-138. (in Japanese) ("Source identification analysis for obsidian lithic artifacts from Arashiyama2 site").

Warashina, T., \& Higashimura, T., 1987b, 東麓郷 1 - 2 遺跡出土の黒曜石遺物の石材産地 分析. In: 東麓楖 $1 \cdot 2$ 遺跡, (Sugiura, S., Ed.), Furano town board of education, Furano: p. 83-108. (in Japanese) ("Source identification analysis for obsidian lithic artifacts recovered from Higashirokugou1 • 2 site”). 
Warashina, T., \& Higashimura, T., 1988, 日進 2 遺跡出土の黒曜石遺物の石材産地分析. In: 日進 2 遺跡 ·日進 31 遺跡, (Suzuki, K., Ed.), Nayoro-city board of education, Nayoro: p. 69-82. (in Japanese) ("Source identification analysis for obsidian lithic artefacts recovered from Nisshin 2 site").

Warashina, T., \& Oguma, H., 2003, 新潟県古瀬ヶ沢洞窟・室谷洞窟遺跡出土黒曜石製遺 物の原産地分析. 長岡市立科学博物館研究報告, 37: 107-118, the Nagaoka Municipal Museum of Science, Niigata Prefecture. (in Japanese) (“Areas Identification of Obsidian Artifacts from Kosegasawa Cave Site and Muroya Cave site, Niigata Prefecture").

Yamada, S., 2006, 北海道における細石刃石器群の研究. Rokuichi shobou, Tokyo. 244 p., (in Japanese) (“A Study of Microblade Assembrideges in Hokkaido, Japan”).

Yoshitani, A., 2001, 北海道旭川市に分布する遺跡から出土した黒耀岩の原産地の推定 について. In: 桜岡 5 遺跡, (Tomoda, T., et al. Eds.), Asahikawa city board of education, Asahikawa: p. 58-65. (in Japanese) ("Source identification analysis for obsidian recovered from sites distributed in Asahikawa city, Hokkaido"). 